\title{
Albania: The Linkage between Infrastructure Development and Sector Strategic Objectives is Crucial for Achieving Results and Sustainability in the Sector
}

\author{
PhD. Arben Bakllamaja \\ Lecturer, Tirana European University. Economic Faculty \\ E_mail abakllamaja@gmail.com, Tel: +355 689019431 \\ PhD. Nehat Çollaku \\ Manager of Improved Natural Resources Mnagement Project \\ Ministry of Environment, Forests and Water Administration \\ E-mail: nehatcollaku@gmail.com, Tel. +355685756660
}

Doi:10.5901/mjss.2013.v4n3p659

\begin{abstract}
A key question in the development theory is why the linkage between the infrastructure and development is not strong in developing countries? This leads to the next logical question, what is the impact of infrastructure development on the growth of economy, and how we measure it. The importance of the linkage between the infrastructure and development is addressed quite extensively in the international literature. Today, many quantitative and qualitative assessments are used at length to analyze and assess the impacts of programs and projects are having on the sector development, economic and social distribution, social change, fiscal balance, environmental change, quality of public services and overall quality of life. There are serious issues at the project level, as well as at the sectorial and national level relating to design, implementation, and capacity building that relates to the achievements of the development objectives and their sustainability. How do we link the objectives with expected outcomes, and how the target values set in the programs and projects would improve those at sectorial or regional levels? The international organizations try to capture these linkages through their evaluation of programs and projects they finance in the developing countries, based on a standard methodology and criteria. The hypothesis of this paper is: "The impact of the programs and projects on the sector strategic objectives is assured if the linkage between the infrastructure and development objectives at the project and sectoral levels is strong at all stages of the project cycle, sector policies are built in the project, and the sector reforms continues steadily."
\end{abstract}

Keywords: Infrastructure programs, projects linkages, sector development objectives, results indicators, impacts assessment

\section{Introduction}

All governments invest billions of dollars or euros in the infrastructure of their countries, but the impact of their investments is uneven on the growth. Albania has invested more than one billions of dollars in the past two decades. Because of these investments infrastructure in Albania has been developing quite a rapidly. This development was associated by sector reforms, which comprised institutional changes in the delivery of its infrastructure services, private sector participation in service delivery, establishment of regulatory entities ${ }^{1}$, liberalizing the price for the infrastructure public services to achieve the cost recovery level, addressing the subsidy issues, improvement of service quality, and making these improvements sustainable.

A new development on the road is the market integration in the Balkan countries; due to EU enlargement process it has required the integration of the national infrastructure systems with the regional systems. Therefore, big funding sources shall be needed to finance investments projects to meet the future demand for economic growth and integration, and for the wellbeing of the people. The Water Sector Strategy estimates that the country needs to invest over 100 million Euro annually in the coming years in order to improve service quality and sustain the sector achievements. ${ }^{2}$

What we observe now is that the public infrastructure services in the electricity, water and sanitation, roads is still

\footnotetext{
1 The regulatory function was basically separated from other public sector responsibilities, to monitor the monopolistic behaviors of natural monopoly services, encourage competition, and reduce the perception of risk by potential private investors. The introduction of independent regulators signaled the commitment to end self-regulation and the willingness to reduce political interference in regulatory designs.

2 Albania National Water Supply and Sewerage Services Sector Strategy 2011-2017, September 2011, pg. 46
} 
below the European standards, including countries in the Balkan region. A number of questions lie in the program and project cycle, starting from preparation till implementation and completion.

Key issues raised by the Evaluation Cooperation Group of the International Financial Institutions in this conjunction are: a) various international organizations and government act differently through different stages of project cycle to achieve the development objectives, b) the sector reform is seen more within the project fence rather as a continuous process that affects the degree of sustainability of development. ${ }^{3}$

The other issue is how evaluation is done to measure this linkage? On the evaluation of the programs that EU finances, the EC has raised the concern that "However, cooperation between funding agencies in evaluation would require some compromises. As all the agencies concerned have their own ways of codifying and regulating the evaluation process, joint evaluation would often need a significant element of mutual adjustment."4

The National Strategy for Development and Integration (NSDI) 2007-2013 has addressed properly the need for development of the infrastructure closely linked with its national objectives and even broader in the region. As per the NSDI, "The development of the national transport network infrastructure will facilitate the movement of people and goods, will bring markets closer and as a result will promote business, will increase access to important basic services, such as health and education with a direct impact on the citizens' living standards, while the development of the national road network, cross-border roads, port facilities and airports will help achieve greater integration with the region and the European single market; Investments with an environmental dimension will help sustain economic growth, reduce significant costs to the economy (for example, on public health) and meet EU standards; Electrical energy generation will increase, and the quality of transmission and distribution will improve to ensure security of supply within the framework of commitments to open the domestic energy market and participate in the regional energy market". ${ }^{5}$

Is the Government of Albania measuring the impact of the infrastructure development on the growth of the country? The available reports from the ministries show a weak evaluation of this linkage.

This Paper will address these issues in Albania, based on a few case studies of projects and programs in Albania financed by IFIs sources and domestic as well where different cases have been introduced with various results.

The structure of the paper is as follows. The Paper begins by describing the importance of the linkages between the program and projects in infrastructure and sector strategies. In section III it analyzes how can policy-makers assure that programs and projects are well interconnected with the sector development objectives? Section IV provides an analysis of how the implementation of the programs and projects can ensure sustainability of the project outcomes?

Section V focuses on measuring the effects of the projects and programs through proper indicators. Section VI provides main conclusions drawn from the review of the country's experience and analysis issues of how to best interconnect infrastructure programs and projects with sector developments.

\section{How can policy makers assure that programs and projects are well interconnected with the sector development objectives?}

The policy makers in the country are always under the pressure of low capacity in the administration and intervention of politics when it comes to the government budget investments, which affects the quality of the programs and project designs. Another standard we witness is the one developed by international organizations in their projects design.

The experience of these IFIs tell us that, in the program or project cycle the design stage is very crucial to build in the project or program the necessary linkage between their objectives and sector strategies. What these organizations require in this stage are the following.

First, the country should develop a proper sector strategy and legislation that underpins these strategies. Having said that, the international organizations, like the World Bank ${ }^{6}$ and the European Community have assisted the recipient country to design infrastructure sector strategies and policies, and developed accordingly proper legislation. Meeting the requirements of Acquis legislation is fundamental for this linkage from the EC perspective.

Over the past two decades, Albanian governments have developed strategies that have been legislated by the parliament to endorse reforms in infrastructure sectors such as transport, water and sanitation and electricity, along the

\footnotetext{
${ }^{3}$ The Evaluation Cooperation Group of the International Financial Institutions, African Development Bank, Asian Development Bank, European Bank for Reconstruction and Development, European Investment Bank, Inter-American Development Bank, International Monetary Fund, and the World Bank Group "The Nexus Between Infrastructure and Environment" June 2007, Evaluation Brief 5.

${ }^{4}$ Directorate General External Relations Directorate General Development EuropeAid Co-operation Office Joint Evaluation Unit, Evaluation Methods for The European Union's External Assistance, Methodological Bases for Evaluation Volume 1, EC 2006, pg. 5.

${ }^{5}$ National Strategy for Development and Integration 2007-2013, March 2008, pg.42-43

${ }^{6}$ World Bank Independent Evaluation Group, Annual Review of Development Effectiveness 2006 Getting Results, pg.23
} 
requirements of these international organizations.

The above created the basis for connecting the sector long term goals with the proposed programs and or projects financed by international organizations and the government as well. The infrastructure projects financed by the World Bank are required to explicate this connection, through the "Strategic Context and Rationale" section of the Project Appraisal Document (BOX 1).

\section{Box 1.}

1. Strategic Context and Rationale, 1. Country and Sector Issues. "In promoting efficient water supply and sanitation services in connection with natural resource management, the Project supports the GPRS ${ }^{7}$ and CAS goals. Also, in line with the decentralization strategy in the GPRS and the CAS, the Project will promote management of water and wastewater services at the local level by setting up transparent and inclusive mechanisms at the level of local governments for decision-making, implementation and management of natural resources and public services." 2. Main Sector Issues and Government Strategy. "The Bank and the donor community support the Government's general outline of a sector strategy which involves a two-tier approach: focusing in the very short-term on urgent repairs to the systems, but continuing in parallel with a medium-term program that will support sector reforms".

Source: World Bank Project Appraisal Document, Municipal Water and Wastewater Project, pg.2,4, December 2002

Second, in the project design the sector long term goals must be well incorporated in the program or project development objectives. A good example is the same above project. The Project Development Objective (DPO) was: "The overall development objective of the Project is to improve water supply and sanitation services in four participating cities and achieve financial viability in their water utilities, by introducing a new incentive-based multi-city management contract approach." ${ }^{8}$ This DPO contains the following key sector strategy objectives: a) water supply safety and quality, b) expansion of services to the poor and needy population, c) duration of hours of supply, d) Private Sector Participation, and e) financial viability of utilities, to ensure efficiency and sustainability.

BOX 2 shows how the development objectives of Natural Resources Development Project are connected with the sector and national objectives.

\section{Box 2.}

The project contributes to two key pillars of the government's National Strategy for Socio-Economic Development. It is consistent with the National Environmental Action Plan, updated in 2000. The project objectives supports the three key elements of the 2002 Country Assistance Strategy (CAS): poverty alleviation and human development; sustainable private sector led growth in hilly and mountainous areas; and improved governance and institution building, with a focus on building the capacity of communes and user associations to manage resources sustainably and transparently, as well as of Government institutions at central, regional and local level to support sustainable natural resources management.

The project global environmental objective is to reverse severe degradation of upland and mountainous erosion-prone lands, and sediment runoff to the Adriatic Sea, through rehabilitating and sustainably managing natural resources, including globally significant biodiversity. The 2003 Albanian Biodiversity Strategy calls for measures to reduce degradation and erosion of agricultural lands and to incorporate ecological considerations into the use of forest resources.

Source: World Bank Project Appraisal Document May 2005, Natural Resources Development Project, pg.4

Third, is setting up realistic objectives of the programs and projects? This has been always quite e big challenge of all financiers of the infrastructure programs and projects. The reason is that, the tendency of international organizations, like the World Bank is to set ambitious objectives, which do not necessarily match the reality of the country, and the outcome of this is rating them unsatisfactory when projects are completed, or are rated as moderately satisfactorily when it is not justified. In this case de-facto they are pre-rated unsatisfactory since at the design stage of the project or a program.

The example given in the below BOX 3 indicates that the Government of Albania has agreed with the World Bank to reduce or remove operating subsidies for water utilities in four years in the Development Policy Operation Program of 2007. This objective did not materialize.

\section{Box 3.}

Accordingly, DPO 1 supports the following action: - Prepare a first draft of water sector policy options paper, including proposed actions to: (i) transfer water assets from the central to local government; (ii) reduce or remove operating subsidies for water utilities over the next 4 years (which implies phased increases in cost recovery and improved efficiency by water companies); (iii) design a performance-based policy for investment transfers to water utilities. The policy options note will be a strategic document for decentralization of the water sector to ensure financially self-sustaining water utilities, and will also lay out a long-term vision for the sector. This options paper would then feed into an update of the GOA Water Sector Strategy. ${ }^{9}$

Source: World Bank First Development Policy Operation to Albania

\footnotetext{
${ }^{7}$ Growth and Poverty Reduction Strategy, 2001

8 World Bank Project Appraisal Document, Municipal Water and Wastewater Project, December 2002

9 International Development Association Program Document for A Proposed Credit In The Amount of SDR 6.8 Million (US\$10 Million Equivalent) for a First Development Policy Operation to Albania February 28, 2007. Par.82
} 


\section{How the implementation of the programs and projects can ensure sustainability of the project outcomes?}

The experience has proved that a number of programs and projects move away from policies and measures for their implementation designed in the project during implementation.

A typical example is the construction of the break water at the mouth of the Drini river without having the EIA prepared and approved, as requested by the Albanian Law. Because of the risks that the construction of the break water at the mouth of the Drini river, would have on the Kune Vain Managed Reserve without having the EIA report prepared and approved by the Ministry of Environment, the World Bank threatened to suspend disbursements from the GEF grant. Furthermore, the World Bank requested suspension of further breakwater construction until the EIA Report is approved. The Ministry of Environment reacted positively to these demands, and the GEF funding was not suspended, because an International Organization requested the compliance with the EIA during the implementation of the Integrated Water and Ecosystems Management Project.

Most of the water projects funded by the World Bank in the water and sanitation sector have set as one of the key targets, removal of operating subsidies through increasing tariffs, improving operating and financial efficiencies, which affect the fiscal balance of the budget either at local or at the national level. In reality none of the projects have achieved this target value until their completion. The main reason was lack of political will to implement properly the tariffs policies, and take all measures to establish corporate governance in the management and operation of public companies, instead of interfering politically in the business of these companies.

During the implementation of the Albanian transport project, the demand for protecting the area of the River Mati from flooding because of the Milot-Rreshen road, prompted the revision of the EIA in accordance with Bank procedures, which has been well guarded by the World Bank project team. To ensure application of the relevant mitigation measures, the Project included two unusual Project covenants related to the implementation of strengthening of flood protection works on the north and south sides of the River Mati by June 2007 and December 2007, respectively. Because of the proper implementation of the flood protection work, these areas were not adversely affected during the floods of 2010 and 2011. ${ }^{10}$

Another key issue with the project implementation is the discordance between the project duration and the pace of the sector reform measures. None of the policy measures agreed in the DPO with the Government, as described in the below BOX 4, were implemented during the implementation of this program.

\section{Box 4.}

Subsequent DPOs will support adoption of the water sector policy options paper, followed by revision and adoption of a revised Water Sector Strategy. This would be followed by the commencement of implementation of the revised Strategy, and transfer of an increasing number of water assets to Local Governments (LGs), as well as the signing of an agreement with each LG and utility. In addition, the Monitoring and Benchmarking Unit needs to be scaled up to cover the whole country and data quality needs improvement. The DPOs would support government monitoring and benchmarking of the whole sector and making all the results public. ${ }^{11}$

Source: World Bank First Development Policy Operation to Albania

This time lag has been observed in other projects financed by the World Bank in Albania.

It is customary for the international organizations to see the programs and projects they finance closely linked with enhancing good governance and institutional capacity in the regulatory system and relevant government organizations, establishing corporate governance in the public companies providing public services. This is one of the most critical factors towards the sustainability of the outcomes of the programs and projects, and the most difficult objective to achieve during the project implementation. In reality this objective is reduced to some training, new program software, and institution reorganizations.

\section{How the results indicators ensure the linkage of the projects and programs with the sector and national levels}

The new theory and practice tell us that evaluation starts with the project design, where all relevant organizations try to build in the programs and projects results of the objectives, with results indicators and target values. This is how you appraise the expected results by looking forward until the project completion. It is well know that to ensure the linkage of the projects and programs with the sector and national levels requires linking objectives with their results indicators and

\footnotetext{
10 World Bank, Implementation Completion and Results Report, Transport Project December 2011, pg.9

11 International Development Association Program Document for A Proposed Credit In The Amount of SDR 6.8 Million (US\$10 Million Equivalent) for a First Development Policy Operation to Albania February 28, 2007. Par.83
} 
extensive information to empirically analyze the effects.

Developing proper indicators to measure the results of the project or a program is facing two major constraints in the case of Albania: a) difficulties to measure during the project implementation, b) indicators are not well linked with the expected results until the end of the project, and c) lack of capacity in the project implementation unit to monitor the progress indicators are making and reporting regularly. The World Bank financed projects defines the project outcome indicators related to the program or project development objectives and intermediate outcome indicators related to the expected results from each component of the project.

The below BOX 5 and 6 show a particular case where the results indicators have been changed after the Mid Term Review of Integrated Water and Ecosystems Management Project, and of the Natural Resources Development Project.

Box 5.

The Global Environment Objectives (GEO) were not changed although the values of performance indicators related to two GEOs were modified during the Mid-Term-Review as follows:

1.Improved health of posidonia oceanic (seagrass) meadows: biomass per surface unit; shoot density, epiphyte growth and area covered. reason for change Sea grass is a suitable long-term indicator. Even with $100 \%$ successful implementation it is not expected that effects on seagrass become visible within project lifetime.

2. Improved biodiversity in Kune Vain Managed Area regarding the following flagship Classes: Malachofauna, Herpetofauna, Avifauna, and Mammalia. - reason for change: End-of-project target values have been reduced to three basic shortterm biodiversity indicators These were the most realistic changes expected within the (short) lifetime of the project. Changes of other taxa like Malachofauna, Herpetofauna and Mammalia have long-term perspective.

Source: World Bank, Implementation Completion and Results Report, Integrated Water and Ecosystems Management Project, June 11, 2010, pg.3.

Box 6.

The direct measurement of sediment flows into the Adriatic Sea is impossible, from a technical point of view (too many confounding factors) and from a cost point of view (that is a huge and costly research program, much larger than the project itself. What is possible, and supported by the local research, is an estimate of reduced erosion from various land management investments, which can be extrapolated to mean reduced flows of sediment to local water courses. As such, this indicator has been modified to be the number of hectares of improved land management, namely: reforestation, fruit tree plantation, vineyard plantation, establishment of cultivated pasture, pasture/rangeland management, and exclusion areas.

Source: World Bank, Mid-Term mission Report, Natural Resources Development Project, pg. 35 June 2008.

An important challenge here is how the project development results indicators are in line with the sector policies and their objectives at the design stage.

The below BOX 5 gives an example on how the sector objectives are linked with the growth, and measures suggested are linked with the results indicators in the Development Policy Operation Program.

\section{Box 6.}

The objective: Improve fiscal sustainability of water services.

The aim of the DPO is: To contribute to growth, the sector needs to invest more in wastewater collection and treatment.

The DPO contribution: will assist the government in clarifying some of the outstanding policy issues and in implementing the strategy. In particular, the DPO will support the government to improve the budget allocation system to water utilities in order to provide incentives for improvements in their technical and financial performance. It will also assist in implementing the decentralization policy by clarifying issues around asset transfer and utility management.

Expected results: 1) Reduction in utility operating subsidies by 10 percent per year (national average). 2) Performance contracts signed with an increasing number of utilities (which would be a critical input into the revised scheme of operating subsidies and investment subsidies).

Source: World Bank First Development Policy Operation to Albania, pg.20-22

As we see from the above, the results indicators were not well connected to the objectives of the DPO in the sector. The reason of reducing results indicators to two quantifiable indicators is that quality indicators are difficult to measure and the project team faces lots of pressure from the government.

One of the success stories is the establishment of the Monitoring and Benchmarking system of the performance of water utilities across Albania within the Ministry of Public Works and Transport. In this program we see that the sector's indicators are well aligned with the Monitoring and Benchmarking system indicators. This has helped that the project indicators to be well-matched with the indicators reported from the Monitoring and Benchmarking unit for the entire sector.

This is a very good step towards establishing solid indicators for the sector and further evaluating the project indicators against the sector ones, and the objectives layout in the sector strategies. 
What is missing in this field is that there is a lack of available reports and other information on the indicators that all international organizations involved in the infrastructure sector are using, what are the results and how comparing with the sector indicators and sector strategies' objectives.

\section{Conclusion}

1. The government organizations have to learn from the experience of big international organizations, and in particular the World Bank and the EU, on how to establish a solid methodology of building in the project design the linkage between the objectives with expected outcomes in the programs and projects with sector strategies. Thus, the gap between the two standards will narrow down gradually.

2. The government organizations have to learn from the experience of big international organizations on how to link the expected results with indicators and target values set in the programs and projects with those at sectorial or regional levels in the project design?

3. Implementing properly programs and projects requires an effective monitoring and evaluation program and consistency with the policies objectives, and activities that lead to these objectives. However, revising these policy objectives, when they are very ambitious is necessary during the implementation.

4. Maintaining results achieved after completion of the programs or projects, requires continuity of the reform implementation, so to ensure that project outcomes leads to the sector development. Establishing good governance and institutional capacity in the regulatory system and institutions, corporate governance level in the service providers, ensuring proper financial resources to perform their tasks, enhancing capacities of local government units, are seen as paramount for sustaining good results.

5. Establishing monitoring and benchmarking systems at the sector infrastructure level is paramount to create a solid data base of the sector performance and indicators that must be utilized when design programs and projects objectives in connection with the sector performance, and further with the objectives layout in the sector strategies.

6. The cooperation between international organizations and the government in evaluation methodologies and indicators used is a challenge for all engaged stakeholders. The Government should take the lead, as it is in its own interest to regulating the evaluation process, and strengthening joint evaluation so the impact of their investments financing on the country's growth is well measured and reported in a transparent way.

\section{References:}

Independent Evaluation Group (IEG) of the World Bank, "The Nexus Between Infrastructure and Environment From the Evaluation Cooperation Group of the International Financial Institutions. Evaluation Brief 5. The World Bank Washington, D.C. June 2007.

Directorate General External Relations Directorate General Development EuropeAid Co-operation Office Joint Evaluation Unit, Evaluation Methods for The European Union's External Assistance, Methodological Bases for Evaluation Volume 1, EC 2006. International Development Association Program Document for A Proposed Credit In The Amount of SDR 6.8 Million (US\$10 Million Equivalent) For A First Development Policy Operation To Albania February 28, 2007. Par.82

Keshilli i Ministrave, "Strategjia Kombetare per Zhvillim dhe Integrim 2002-2013" Tirane Albania.

World Bank (2005), Infrastructure in Europe and Central Asia, Sustainable reforms and financing, ECA Regional Study

A World Bank Infrastructure Department Europe and Central Asia Region (July 2006), Urban Sector Review

World Bank Independent Evaluation Group, Annual Review of Development Effectiveness 2006 Getting Results

International Bank for Reconstruction and Development, International Development Association and International Finance Corporation Country Partnership Strategy for Albania for the period FY11-FY14

Fondi i Zhvillimit Shqipetar, Raporti i Aktivitetit 2011.

Forumi Shqipetar Social-Ekonomik, Monitorimi i shpenzimeve publike ne infrastrukturen rrugore dhe ujesjelles-kanalizime.

World Bank - Albania Partnership Program Snapshot September 2011.

World Bank, Implementation Completion and Results Report, Transport Project December 2011.

World Bank, Implementation Completion and Results Report, Integrated Water and Ecosystems Management Project, June 11, 2010.

World Bank, Implementation Completion and Results Report, Natural Resources Development Project, pg. 58 February 2012.

Buxheti i vitit 2011, Aneks 1, Formula e Transfertës së Pakushtëzuar - Kriteret dhe Koeficentët.

Albania National Water Supply and Sewerage Services Sector Strategy 2011-2017, September 2011. 